\title{
歯周疾患に打ける炎症の臨床的評価法
}

\author{
勝谷芳文・䪺 良治・白木雅文・岩山幸雄 $*$
}

\section{Clinical assessment on gingival inflammation in periodontal disease}

Yoshifumi Katsutani • Ryoji Nie - Masafumi Shiraki • Yukio Iwayama*

歯周疾患において, 歯肉炎症の臨床的評価法は PMA Index, Gingival Index などの歯肉の色調や形態の変化 を基準としたものが用いられてきた。しかし，これらの 基準は，歯周疾患の現在の activity を表すには不十分で あるとの考光から，歯周ポケットからの出血を基準とす る Gingival Bleeding Index が disease activityにより 近いものとして臨床に用いられている.

従来，集団検診への応用などを目的として，唾液中の 潜血を測定した報告 ${ }^{1-4,6)}$ があるが，全唾液という条件 設定の困難な試料のため，やや精度にかけるきらいがあ った。

今回われわれは，感度の異なる 2 種類の試験紙（へマ スティックス III：マイルス三共, サリバスター：昭和薬 品化工）を用いて，洗口液に拈ける潜血反応と Gingival Bleeding Index との関連性を調べ，歯周疾患の臨床的 評価法への潜血試験紙の応用を検討した.

\section{方 法}

臨床的に歯周疾患を認めない健常者 8 人と，歯周炎患 者 31 人を対象として, 全唾液ならびに洗口液中の潜血反 応と Bleeding Index との関係を調べた。 まず測定前の 食䭒やブラッシングなどの影響をできるだけ除外するた めに 3 回十分にらがいを行わせ，その後30秒間に口腔に 貯留した全唾液に打ける潜血反応を測定，さらに 1 回ら がいを行わせたのち, $10 \mathrm{ml}$ の水道水で30秒間強く洗口 を行わせ,この洗口液に拈ける潜血反応を測定した.つい で, Bleeding Index の測定を行った。潜血反応は，付 属の基準色に従い(一)〜（卅）まで 5 段階の判定を行い， Bleeding Index は, pocket brobing 後30秒に出血の有 無を判定し，全歯面に対する出血（十）の歯面の割合と して百分率で表した。

\section{結 果}

使用した試験紙のへモグロビン水溶液に対する感度を 検討した結果, ヘマスティックス III $0.25 \mu \mathrm{g} / \mathrm{ml}$ 濃度 で潜血陽性（土）を示した。これはサリバスターの約 10 倍の高感度であった

8 人の健常者はいずれも Bleeding Index として $19 \%$ 以下であり, 一方, 31人の歯周炎患者の Bleeding Index はすべて20\%以上であった（表 1).

潜血反応（一〜州）をそれぞれ潜血指数として（0〜 4) の評価を与え, Bleeding Index と潜血指数との相

* Department of Periodontology, Gifu College of Dentistry 岐皋歯科大学齿周病学教室
表 1 Bleeding Index による被検者の分類

\begin{tabular}{|c|c|c|c|}
\hline$\underset{(\%)}{\text { Bleeding Index }}$ & & 被検者数 & $\begin{array}{l}\text { 各群における Bleeding } \\
\text { Index の平均值と標準 } \\
\text { 偏差 }(\%)\end{array}$ \\
\hline $0 \sim 19$ & 8 & 健常者 & $15 \pm 4$ \\
\hline $20 \sim 39$ & 9) & \multirow{4}{*}{ 歯周炎患者 } & $27 \pm 6$ \\
\hline $40 \sim 59$ & 13 & & $48 \pm 6$ \\
\hline $60 \sim 79$ & 4 & & $71 \pm 6$ \\
\hline $80 \sim 100$ & 5 & & $88 \pm 4$ \\
\hline total & 39 & & $44 \pm 24$ \\
\hline
\end{tabular}

関を調べた結果, 唾液における潜血指数は両試験紙とも に Bleeding Index と中等度の正の相関を示した（図 1 $\mathrm{a}, \mathrm{b}$ ).

洗口液においては, ヘマスティックス III 相関係数 0.76 (図 1 c)，サリバスターで相関係数 0.70 (図 $1 \mathrm{~d}$ ) と高い正の相関を示し，洗口液に拈ける潜血反応が Bleeding Index と密接に連動することが示された.

つぎに，潜血反応の程度が歯周炎の gradeをよく反映 し，歯周炎患者のスクリーニングに優れているか否かを 調べる目的で, Bleeding Index の $20 \%$ ごとに区分した 被検者グループに拉ける潜血反応の程度の分布を検討し た（表 2 ）。サリバスターを使用した場合, 健常者 (Bleeding Index 0〜19\%のグループ) を潜血陽性（土以上） と判定することはなかったが，歯周炎患者を潜血陰性と 判定するケースが多く認められた（唾液潜血で 31 人の患 者のうら 10 人, 洗口液潜血で 31 人のらち 22 人).

一方へマスティックス IIは，唾液と洗口液のいずれに 適用した場合でも，歯周炎患者を潜血陰性と判定した のは 31 人中 3 人と，スクリーニング漏れはわずかであっ

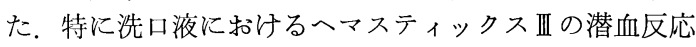
は, 各 Bleeding Index 群に拈ける潜血反応のバラつき も少なく，Bleeding Index 群を段階的に正しく反映す ることが示された.

\section{考 察}

歯周疾患の臨床的評価法への潜血試験紙の応用につい ては, 岩山ら ${ }^{1-3)}$ が唾液潜血と PMA Index との関係か

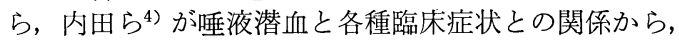
唾液潜血反応が歯肉炎の評価に有用であることを報告し ている。 Tenovuo 5 5 は, 潜血試験紙を直接歯肉溝に apply し，歯肉溝參出液における潜血反応を検討した。 さらに神山吕も Bleeding Index との関係から歯周疾患 の臨床的評価法としての唾液潜血試験紙の有用性を報告 している.

これらの研究で使用された潜血試験紙はいずれもへマ スティックス III 同様に，へモグロビンの触媒作用下に 
表 2 Bleeding Index により区分した被検者グループに扣ける潜血反応の分布

\begin{tabular}{|c|c|c|c|c|c|c|c|c|c|c|c|c|c|c|c|c|c|c|c|}
\hline \multirow{3}{*}{$\begin{array}{l}\text { Bleeding Index } \% \\
\text { (被検者数) }\end{array}$} & \multicolumn{6}{|c|}{ 唾 } & 液 & & & & & & & 洗 & \multicolumn{2}{|c|}{ 口 } & \multicolumn{3}{|l|}{ 液 } \\
\hline & \multicolumn{5}{|c|}{ ヘマスティックス II } & \multicolumn{5}{|c|}{ サリバスター } & \multicolumn{5}{|c|}{ ヘマスティックス III } & \multicolumn{4}{|c|}{ サリバスター } \\
\hline & - & \pm & + & H & H & - & \pm & + & H & H & - & \pm & + & $H$ & Ht & - & \pm & + & H H \\
\hline $0 \sim 19$ ( 8$)$ & $4^{*}$ & 4 & & & & 8 & & & & & 6 & & & & & 8 & & & \\
\hline $20 \sim 39$ ( 9$)$ & 1 & 3 & 2 & 2 & 1 & 3 & 4 & 1 & 1 & & 1 & 5 & 3 & & & 8 & 1 & & \\
\hline $40 \sim 59$ & 1 & 3 & 1 & 4 & 4 & 4 & 2 & 3 & 3 & 1 & 2 & 5 & 5 & 1 & & 12 & 0 & 1 & \\
\hline $60 \sim 79(4)$ & 1 & & 3 & & & 3 & 1 & & & & & 1 & 2 & 1 & & 2 & 2 & & \\
\hline $80 \sim 100(5)$ & & & & & 5 & & & & 5 & & & & & 3 & 2 & & & 3 & 2 \\
\hline
\end{tabular}

*数字は被検者の数を表す.
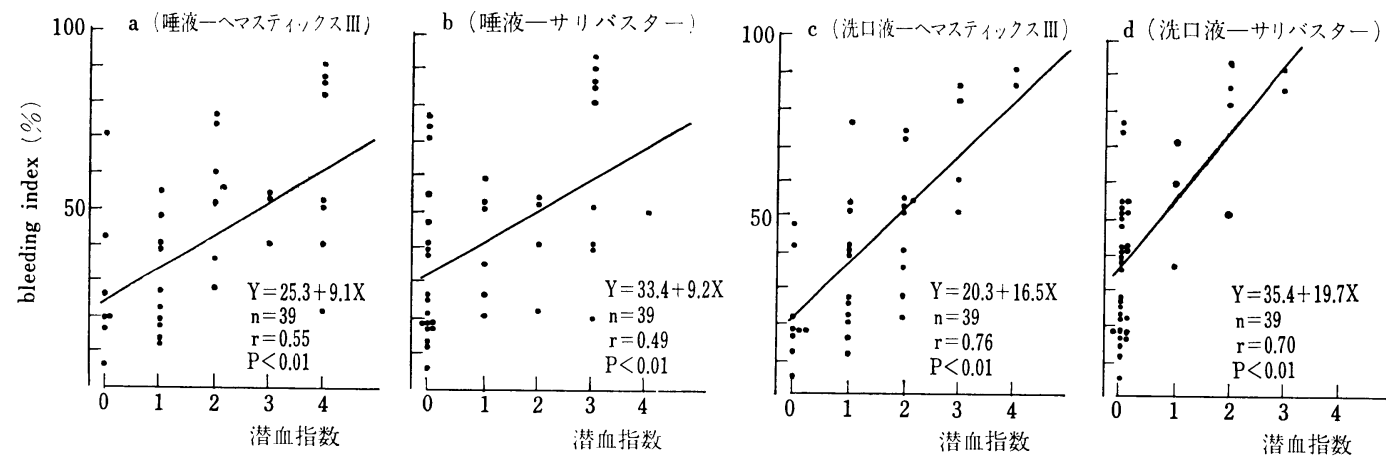

図 1 潜血指数と Bleeding Index との相関

orthtolidine と過酸化物が反応して青緑色を呈するもの であるが，へモグロビンに対する感度はそれぞれ異なっ ている。へモグロビン水溶液ならびにヒト希釈血液を用 いて試験紙の呈色度を調べた結果，へマスティックス II は, 岩山らが用いた試験紙へマコンビスティックス（マ イルス三共) の約 50 倍, 内田らが用いた潜血試験紙 (和 光純薬）の約 10 倍の高感度であった。

過去の報告では, Tenovuo らの報告を除いてすべて唾 液に打ける潜血を被検対象として研究されている。唾液 潜血反応は, 歯周ポケットあるいは歯肉辺縁からの微量 の出血が唾液中に混入したものを測定するものであり, 純唾液では呈色しない. したがって, 唾液という, 個体 間であるいは同一個体においても測定時の種々の条件で 分泌量が異なる試料を対象とするよりも，洗口液のよう に一定条件で採取できる試料を対象とするほうがより正 確であろうと考えられる。事実, 本実験結果では洗口液 に拈ける潜血指数が Bleeding Index と高い正の相関を 示した。 しかし，本実験で用いた30秒間の洗口液といら 条件では, へマスティックス III比べてサリバスターの 場合, 歯周炎患者のスクリーニングには試験紙の感度と して不十分であった，なお，本実験で使用した両試験紙 の感度では, 水道水に含まれる各種イオンによる呈色反 応あるいは白血球や霜周細菌由来のペルオキシダーゼに よる呈色反応は認められなかった。

以上の結果から, 洗口液に打恀るマスティックス III
の潜血反応は, Bleeding Index を指標とした歯周炎の 程度をよく反映する優れた臨床的評価法であり，歯周炎 患者のスクリーニングにも有用であることが示された。 洗口液に打ける潜血の測定は方法も簡便であり，日常臨 㦿に打ける診断や治療効果の判定への利用, 歯周炎患者 のモチベーションへの利用, 患者自身のホームケアーに 扣ける自己評価への利用，さらに，きたるべき高齢化時 代に拉ける成人歯科検診での歯周炎患者のスクリーニン グへの利用など，広く活用できる優れた臨床的評価法で あると考えられる。現在, このよらな方面への応用を目 的として, 測定条件や試験紙の感度についてさらに検討 を重ねている。

\section{文 献}

1）岩山幸雄, 横溝一郎 - 他：阪大雬誌 16:83-86, 1971.

2) 野村慶雄, 岩山幸雄 - 他：日歯周誌 15:248-253, 1973.

3）野村慶雄, 岩山幸雄 - 他：日菌周誌 18：56-62, 1976.

4) 内田武志, 岡本 莫 - 他：日歯周誌 18:406-413, 1976.

5) Tenovuo, J., Antonen, T.: J. Clin. Periodontol. 5: 206-212, 1978.

6）神山義信：日歯周誌 25：356-361，1983. 